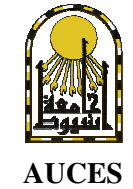

\title{
ASSESSMENT OF ELDERLY KNOWLEDGE ABOUT URINARY TRACT INFECTION IN ASSIUT CITY
}

\author{
Saieda Abd-Elhamed Abd-Elaziz*, Hoda Diab Fahmy \\ Ibrahiem**, \\ Neama Mohammed El-Magrabi ${ }^{* *}$ and Safaa Rashad \\ Mahmoud $^{* *}$ \\ *Geriatric Nursing Department, Faculty of Nursing, Assiut University \\ **Community Health Nursing, Faculty of Nursing, Assiut University
}

\section{ABSTRACT:}


Aim: The objectives of this study are to promote health of elderly people with urinary tract infection, and to assess elderly knowledge about urinary tract infection in Assiut City.

Subject \& Methods: The study was carried out at two setting (geriatric club in legitimate assembly) and (geriatric club in cultural center). The total number of studied sample was 100 elderly. Two tools are used in this study: 1)structured interview sheet, which includes, personal data: such as age, gender, marital status, etc .. 2) Tool two, which included definitions of UTIs, causes, physiological changes that occur in elderly and predisposing factors of disease, Signs \& symptoms, complications, treatment, and Steps for prevention and control of UTIs. Data was collected in the period from June 2008 to December 2008.

Results: of the present study; the mean age group of the studied sample was (was $63.9 \pm 4.07$ group), the majority of the studied sample (83\%) were female, also more than half of the studied sample (55\%) were widows. Three quarter of studied female (77.1\%) stated diabetes mellitus, while the majority of the studied male (88.2\%) stated enlargement of prostate as one of the most common disease among elderly men that lead to UTIs. Three quarter of the studied sample $(74.0 \%)$ stated that Inflammation and damage of the kidney one of the most complication of UTIs, \& most of the studied sample (98.0\%) stated that good personal hygiene from front to back after urination is one of the most important methods to control UTIs.

Conclusion: serious lack of knowledge about urinary tract infection among the study sample.

Recommendations: Presence of gerontological nurse at geriatric to follow elderly people and give them health education is very important, different seminars at geriatric club can be done about interested topics for elderly people such as: normal changes, common health needs and problems for elderly people, geriatric club library should be rich with specific book about the physiological changes and common health problems among elderly people, increasing elderly awareness about the importance of periodic check up to detect early health deviation to make early management and to prevent complication through: Health education and focus group discussion for elderly.

\section{INTRODUCTION:}

Aging of the population is a relatively new phenomenon all over the world. Life expectancy for the whole world, which today is 66 years, will become 73 years by 2025 . The Central Intelligence Agency, (2007) reported that the total population of Egyptian people were 78.9 millions at the end of July 2006, while the 65 years and over were 3.5 millions. Also, the

Egyptian life expectancy increased to 68.7 years for male and 73.9 years for female people.

Urinary tract infection is an infection that can happen anywhere along the urinary tract. The urinary tract includes the: Bladder,
Kidneys, Ureters, and Urethra. infections involving the upper or lower urinary tract. (Smelters, et al., 2008).

Urinary Tract Infections (UTI) may appear as a variety of disorders. Infections may broadly classify as upper and lower UTIs, based on the patient's symptoms. Terminology may specifically delineate the site of inflammations or infection. Examples of terms are pyelonephritis' (involvement of kidneys and kidney pelvis) and cystitis (involvement of bladder). Lower UTIs involve the urinary bladder (cystitis), urethra (urethritis) and prostitis. Upper UTIs may 
involve kidney and renal pelvis (pyelonephritis). (Basavanthappa, 2003).

The elderly, especially those residing in long-term-care facilities, more commonly have Asymptomatic Bacteriuria (ASB) than the general population. About $25-50 \%$ of women and $15-40 \%$ of men living in long-term-care facilities have ASB. The prevalence rates in elderly women and men outside of the nursing home are $10.8-16 \%$ and $3.6-19 \%$, respectively.. (Nicolle, et al., 2005).

There are many risk factors for UTIs in elderly, such as atrophic urethritis, atrophic vaginitis, Benign Prostatic Hyperplasia, (BPH) cancer of prostate, catheter use, genitourinary abnormalities (e.g. vesicorectal fistula), genitourinary calculi, renal and perinephric abscess formation, urinary diversion procedure (e.g. ileal bladder diversion) and urethral stricture (Eidelman, et al., 2002).

Women are at greater risk for UTIs than men, partly because of the relatively short, straight anatomy of the urethra. Retrograde ascent of bacteria from the perineum is the most common cause of acute cystitis in women. Host factors such as changes in normal vaginal flora may also affect the risk of UTIs. (Beisel, et al., 2002).

Management of UTIs are treated with an antibiotics. The choice of drug depends on the culture and sensitivity tests that identify the offending bacteria and the drugs to which the organism is sensitive. (Takahashi, et al., 2004). Treatment at home includes, increased waterintake, frequent voiding, taking cranberry supplements, as well as taking vitamin $C$ with the last meal of the day can shorten the time duration of the infection Drinking cranberry juice prevents certain types of bacteria from attaching to the wall of the bladder and may lessen the chance of infection (Jepson, \& Craig, 2008).

Gerontological nurse should instruct the elderly and family members on the disease process, ways to prevent recurrent infection, and the treatment regimen. It is important to emphasize that a few simple life style modification can help prevent future urinary tract infection (Roach, 2001).

Nurses can suggest that older adults can take protective measures when they are in very hot and humid environments. Examples of appropriate protective measures are using fans and air conditioners; increasing fluid intake; and avoiding alcoholic, carbonated, and caffeinated beverages. Nurses also need to be aware of the increased potential for adverse medication effects, especially when the older adult is taking more than one medication (Miller, 2009).

Nurses also can suggest that older adults can take protective measures when they are in very hot and humid environments. Examples of appropriate protective measures are using fans and air conditioners; increasing fluid intake; and avoiding alcoholic, carbonated, and caffeinated beverages. Nurses need to be aware of the increased potential for adverse medication effects, especially when the older adult is taking more than one medication. (Miller, 2009).

\section{Study Rational:}


The elderly have greater susceptibility to infection than do younger adults; it is well known that aging is associated with immune dysfunction. Urinary Tract Infection (UTI) is the most common infection in elderly people and it is more sensitive subject for speaking, so this study will assess elderly knowledge about urinary tract infection.

\section{AIM OF THE STUDY:}

\section{General objective:}

-Reduce morbidity and mortality of elderly for urinary tract infection.

-Health promotion of elderly people with urinary tract infection.

\section{Specific objective:}

To assess elderly knowledge about urinary tract infection in Assiut City.

\section{SUBJECT AND METHODS:}

\section{Research Design:}

Cross sectional research design were used in this study.

\section{1-Setting:}

The study was carried out at two setting which affiliated in the West Assiut City (geriatric club in legitimate assembly) and East Assiut City (geriatric club in Cultural Center).

\section{2-Sample:}

Convenient sample of elderly people attending to the previous setting were included in this study, their number were 100 elderly person aged 60 years and above. Total number of elderly people whom were registered in two clubs were 198 elderly. This registration renew every year and the number of elderly for the year of 2008 were 120 elder whom were compliance with presence in the club.

\section{3-Tool:}

A structured interview sheet was developed by the researcher for collection of data. The sheet included the following data:

Part (1):

- Socio demographic characteristics: such as age, gender, residence, marital status, level of education, occupation before retirement.

- Past and present history of disease such as hypertension, diabetes, heart disease, arthritis, osteoporosis, UTIs, bronchial asthma, enlargement of prostate. Past and present history of taking medication for this disease.

Part (2):

This part included questions related to elderly knowledge about urinary tract infection it included:

- Definitions of UTIs, physiological changes that occur in elderly and predisposing factors of disease.

- Signs \& symptoms, complications, treatment, \& steps for prevention and control of UTIs., also source of knowledge.

METHODS OF DATA COLLECTION: 1-Preparatory phase and administrative design:

An official approval letter was obtained. This letter includes a permission to carry out 
the study and explain the purpose and nature of the study.

\section{2-Pilot test:}

- A pilot study was conducted before starting data collection.

- The tools were developed based on a review of relevant literature.

\section{3-Data collection:}

\section{Ethical consideration:}

- The purpose of this study was explained for every interviewed individual that includes directors of the studied clubs, elderly men and women.

- The elderly has ethical right to agree or refuse participation in the study; consent to participate in the study was secured orally and informed that the information obtained will be confidential and used only for the purpose of the study.

\section{Field work:}

a- Purpose of the study was explained, face to face individual interview with elderly were done, completed the sheet for all persons and wrote exactly the answers that the elderly persons given.

b- Data collection was during the period from June 2008 to December 2008, two days weekly, the average number which interviewed was 2-4 elderly per day. The approximate time spent during the filling of sheet was around 30-45 minutes.

\section{Editing Analysis:}

-Frequencies, percentage, mean, standard deviation, etc) was done using computer program SPSS version 11.

- Chi-square test used for analysis of variance. It is considered significant when P-value were less than 0.05 or $(P<0.05)$.

- Using scoring system in knowledge (poor, fair, good). Each correct item in all questions take one degree and the total correct item was 65 point, and the scoring system were judged as: Poor $<40 \%$, Fair $40 \%-<60 \%$, \& Good $60 \%$.

\section{RESULTS:}

Table 1: Represented that $60 \%$ of the studied sample aged between (60-64) years, while $40 \%$ of them aged 65 years and more. The mean age \pm S.D was $63.9 \pm 4.07$. The majority of studied sample $(83 \%)$ were females while the rest of them $(17 \%)$ were males. It was observed that $(17 \%)$ of the studied sample had basic education and nearly half of them $48 \%$ were had secondary education and the rest $(27 \%)$ were had university education. More than half of the studied sample $(55 \%)$ were widows, while the rest were married $(45 \%)$. Concerning job before retirement about $(38 \%)$ were house wife while $(34 \%)$ of them were employee and the rest of them $(28 \%)$ were administrative job.

Table 2: Illustrate that more than one three quarter of studied female $(\mathbf{7 7 . 1 \%})$ stated diabetes mellitus, while the majority of the studied male $(88.2 \%)$ stated enlargement of prostate as one of the most common disease among elderly men that lead to UTIs followed by prostate cancer. 
Table 3: Denoted that the majority of the studied sample $(92.0 \%)$ stated decrease water intake and increase salt intake, while $(\mathbf{8 0 . 0 \%})$ of them stated that lack of personal hygiene is one of the predisposing factors among elderly women. And only more than one fifth of $\mathbf{2 2 . 0 \%})$ of the studied sample stated immobility.

Table 4: Illustrated that the majority of the studied sample stated that abdominal pain $(81.00 \%)$ followed by Headache \& exhausted (76.0\%). While $(\mathbf{4 5 . 0 \%})$ of them stated Nausea\& vomiting as signs and symptoms of upper UTIs. And only 3.0\% of them stated painful urination.

Table 5: Illustrated that the majority $(82.0 \%)$ of the studied sample stated Burning pain in urination, while $(\mathbf{7 7 . 0 \%})$ of the them stated Confusion and about two third of them (67.0\%) stated that Frequent urination and Chills are the most common symptoms of lower UTIs.

Table 6: Illustrated that about three quarter of the studied sample $(\mathbf{7 4 . 0 \%})$ stated that Inflammation and damage of the kidney one of the most complication of UTIs followed by recurrent infection $(45.0 \%)$. While $(31.0 \%)$ of the studied sample stated kidney stone. Also more than three quarter of the studied sample $\mathbf{7 9 . 0 \% ) ~ h a d n ' t ~ h a v e ~ k n o w l e d g e ~ a b o u t ~ t r e a t m e n t ~}$ of UTIs. While $(\mathbf{1 9 . 0 \%})$ of the studied sample stated antibiotics for treatment of UTIS followed by $(\mathbf{1 0 . 0 \%})$ of the studied sample stated cleaning with antiseptic solution.

Table 7: Illustrates that most of the studied sample $(98.0 \%)$ stated that good personal hygiene from front to back after urination is one of the most important methods to control UTIs followed by Drink from 6-8 glasses of fluid daily and avoid eating salts and spicy foods (94.0\%) and $(91.0 \%)$ respectively. While $(65.0 \%)$ of the studied sample stated use the bathroom as soon as she/he need.

Table 8: Shows that around more than half $(55.0 \%)$ of elderly less than 65 years and more than three quarters $(\mathbf{7 7 . 5 \%})$ of elderly more than 65 had poor score of knowledge and about 45.0 of elderly less than 65 while only $(22.5 \%)$ of elderly more than 65 had a pass score of knowledge. There is statistically significant difference between the study participant's knowledge about urinary tract infections and their age $(P=0.03)$.

Table 1: Distribution of the studied sample according to their personal data \& type of club among elderly people (2008)

\begin{tabular}{|c|c|c|}
\hline Personal data & No. $(n=100)$ & $\%$ \\
\hline $\begin{array}{l}\text { Age (years): } \\
60- \\
65 \text { and more }\end{array}$ & $\begin{array}{l}60 \\
40\end{array}$ & $\begin{array}{l}60.0 \\
40.0\end{array}$ \\
\hline $\begin{array}{l}\text { Mean age } \pm \text { S.D } \\
\text { Range }\end{array}$ & \multicolumn{2}{|c|}{$\begin{array}{c}63.9 \pm 4.07 \\
60-80 \\
\end{array}$} \\
\hline $\begin{array}{l}\text { Gender: } \\
\text {-Male } \\
\text {-Female } \\
\end{array}$ & $\begin{array}{l}17 \\
83\end{array}$ & $\begin{array}{l}17.0 \\
83.0\end{array}$ \\
\hline
\end{tabular}




\begin{tabular}{|c|c|c|}
\hline $\begin{array}{l}\text { Educational level: } \\
\text {-Read and write } \\
\text {-Basic education } \\
\text {-Secondary } \\
\text {-University }\end{array}$ & $\begin{array}{c}8 \\
17 \\
48 \\
27\end{array}$ & $\begin{array}{c}8.0 \\
17.0 \\
48.0 \\
27.0\end{array}$ \\
\hline $\begin{array}{l}\text { Marital status: } \\
\text {-Married } \\
\text {-Widow }\end{array}$ & $\begin{array}{l}45 \\
55\end{array}$ & $\begin{array}{l}45.0 \\
55.0\end{array}$ \\
\hline $\begin{array}{l}\text { Job before retirement of male: } \\
\text {-Employee } \\
\text {-Directors }\end{array}$ & $\begin{array}{c}12 \\
5\end{array}$ & $\begin{array}{l}70.6 \\
29.4\end{array}$ \\
\hline $\begin{array}{l}\text { Job before retirement of female: } \\
\text {-House wife } \\
\text {-Employee } \\
\text {-Directors }\end{array}$ & $\begin{array}{l}38 \\
22 \\
23\end{array}$ & $\begin{array}{l}45.8 \\
26.5 \\
27.7\end{array}$ \\
\hline
\end{tabular}

Table 2: Distribution of the studied sample according to their knowledge about diseases of elderly that leads to UTIs (2008)

\begin{tabular}{|c|c|c|}
\hline Diseases that lead to UTIs ${ }^{\#}$ & No. & $\%$ \\
\hline \multicolumn{3}{|l|}{ In women $(83)$ : } \\
\hline -Don't know & 17 & 20.5 \\
\hline -Diabetes mellitus (DM) & 64 & 77.1 \\
\hline -Kidney stone & 53 & 63.8 \\
\hline -Incontinence & 38 & 45.8 \\
\hline -Uterine prolapse & 30 & 36.1 \\
\hline -Cystitis & 13 & 15.7 \\
\hline -Cyctocele & 11 & 13.2 \\
\hline - Atrophy of vagina & 1 & 1.2 \\
\hline \multicolumn{3}{|l|}{ In men (17): } \\
\hline -Cystitis & 14 & 82.3 \\
\hline -Enlargement of prostate & 15 & 88.2 \\
\hline -Prostate Cancer & 10 & 58.8 \\
\hline -Kidney stone & 12 & 70.6 \\
\hline -Diabetes mellitus(DM) & 11 & 64.7 \\
\hline -Neuralgic bladder & 8 & 47.1 \\
\hline -Urinary catheter & 5 & 29.4 \\
\hline -Incontinence & $\mathbf{0}$ & $\mathbf{0 . 0 0}$ \\
\hline
\end{tabular}

N.B: More than one answers\# 
Table 3: Distribution of the studied sample according to their knowledge about predisposing factors of UTIs among elderly people (2008)

\begin{tabular}{|c|c|c|}
\hline predisposing factors of UTIs ${ }^{\#}$ & No. & $\%$ \\
\hline $\begin{array}{l}\text { In both elderly men and women (100): } \\
\text { - Don't know } \\
\text { - Decrease fluid intake and increase salt intake } \\
\text { - Lack of personal hygiene } \\
\text { - Constipation } \\
\text { - Immobility } \\
\text { - Recurrent sexual intercourse }\end{array}$ & $\begin{array}{c}8 \\
92 \\
80 \\
23 \\
22 \\
4\end{array}$ & $\begin{array}{c}8.0 \\
92.0 \\
80.0 \\
23.0 \\
22.0 \\
4.0\end{array}$ \\
\hline
\end{tabular}

Table 4: Distribution of the studied sample according to their Knowledge about signs and symptoms of UTIs among elderly people (2008)

\begin{tabular}{|c|c|c|}
\hline Signs and symptoms of upper $\mathrm{UTI}^{\#}$ & No. $(n=100)$ & $\%$ \\
\hline - Don't know & 10 & $\mathbf{1 0 . 0}$ \\
\hline -Abdominal pain (radiating to the back on the affected side) & 81 & 81.0 \\
\hline -Headache \&very exhausted & 76 & 76.0 \\
\hline -Nausea\& vomiting & 45 & 45.0 \\
\hline -Frequent urination & 41 & 41.0 \\
\hline - Night sweating & 38 & 38.0 \\
\hline -Chills & 9 & 9.0 \\
\hline -Fever more than 2 day & 7 & 7.0 \\
\hline - Painful urination & 3 & 3.0 \\
\hline
\end{tabular}

Table 5: Distribution of the studied sample according to their Knowledge about signs and symptoms of lower UTIs among elderly people (2008)

\begin{tabular}{|c|c|c|}
\hline Signs and symptoms of lower UTIs ${ }^{\#}$ & No. $(n=100)$ & $\%$ \\
\hline - Don't know & 10 & $\mathbf{1 0 . 0}$ \\
\hline - Burning pain in urination & 82 & 82.0 \\
\hline - Confusion & 77 & 77.0 \\
\hline -Frequent urination & 67 & 67.0 \\
\hline -Chills & 67 & 67.0 \\
\hline -Fever and chills & 20 & 20.0 \\
\hline -Pressure in the lower pelvis & 51 & 51.0 \\
\hline -Painful urination & 8 & 8.0 \\
\hline -Weakness & 6 & 6.0 \\
\hline -Strong urine odor, cloudy and blood in urine & 3 & 3.0 \\
\hline
\end{tabular}

Table 6: Distribution of the studied samples according to their Knowledge about complications and treatment of UTIs among elderly people (2008)

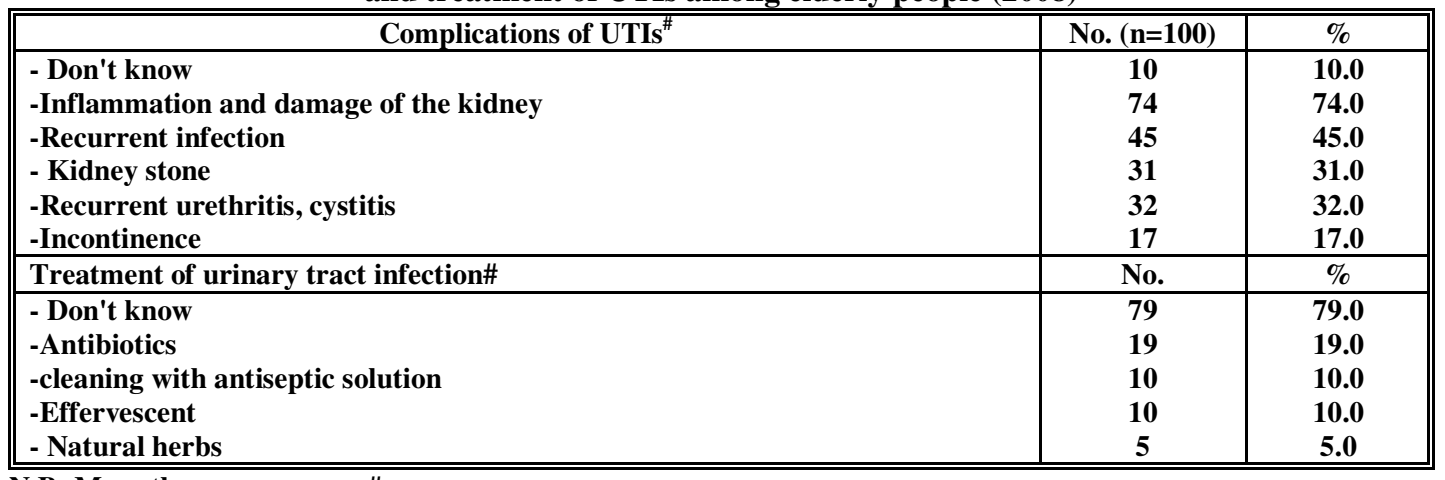

N.B: More than one answers\# 
Table 7: Distribution of the studied sample according to their Knowledge about steps of controlling UTIs among elderly people (2008)

\begin{tabular}{|c|c|c|}
\hline Steps\# & No. $(\mathbf{n}=\mathbf{1 0 0})$ & $\%$ \\
\hline 1-Good personal hygiene from front to back after urination & 98 & 98.0 \\
\hline 2-Drink from6-8 glasses of fluid daily & 94 & 94.0 \\
\hline 3-Avoid eating salts and spicy foods & 91 & 91.0 \\
\hline 4-Use the bathroom as soon as she/he need & 65 & 65.0 \\
\hline 5-Wear cotton undergarments and avoid tight clothes & 57 & $\mathbf{5 7 . 0}$ \\
\hline 6- Avoid caffeine, carbonated beverages, and alcohol & 56 & 56.0 \\
\hline 7-Boiling under wear and expose o sun rays & 42 & 42.0 \\
\hline 8-Eat foods with high acids content such as nuts, plums and whole grain breads and cereals & 8 & 8.0 \\
\hline 9-Drink cranberry juice & 6 & 6.0 \\
\hline 10- Avoid bubble baths and strong bleaches and cleansing & 5 & 5.0 \\
\hline
\end{tabular}

N.B: More than one answers\#

Table 8: Total knowledge score of the studied sample in relation to their age

\begin{tabular}{|c|c|c|c|c|c|c|c|}
\hline \multirow[t]{2}{*}{ Age } & \multicolumn{2}{|c|}{$\begin{array}{l}<65 \text { years } \\
(\text { No }=60)\end{array}$} & \multicolumn{2}{|c|}{$\begin{array}{c}>=65 \text { years } \\
(\text { No }=40)\end{array}$} & \multirow{2}{*}{ DF } & \multirow{2}{*}{$\mathbf{X}^{2}$} & \multirow{2}{*}{ P-value } \\
\hline & No. & $\%$ & No. & $\%$ & & & \\
\hline \multicolumn{8}{|l|}{ Knowledge: } \\
\hline Poor & 33 & 55.0 & 31 & 77.5 & 1 & 5273 & $003 *$ \\
\hline Pass & 27 & 45.0 & 9 & 22.5 & & & \\
\hline
\end{tabular}

(*) Statistically significant at $\mathbf{P}<0.05$

Figure 1: Shows that more than half $(58.8 \%)$ of males and $65.1 \%$ of females had poor score of knowledge and $41.2 \%$ of males and more than one third $(34.9 \%)$ of female had a pass score of knowledge. There is no statistically significant difference between the study participant's knowledge about UTIs and their sex $(P=0.782)$.

Figure 2: Display that more than half of married elderly and more than two thirds of widow elderly $(57.8 \%, 69.1 \%)$ respectively had a poor score of knowledge compared to more than two fifth $(\mathbf{4 2 . 2 \%})$ of married elderly had a pass score of knowledge. There is no statistically significant difference between the total score of knowledge about urinary tract infection and their marital status $(P=0.148)$.

Figure 3: Shows that, more than two thirds $(70.0 \%, 68.8 \%)$ of elderly with basic and secondary education respectively, \& nearly half of them $(48.1 \%)$ with university education had poor score of knowledge. There is no statistically significant difference between the studied sample and their level of education $(\mathbf{P}=\mathbf{0 . 2 4 5})$. 


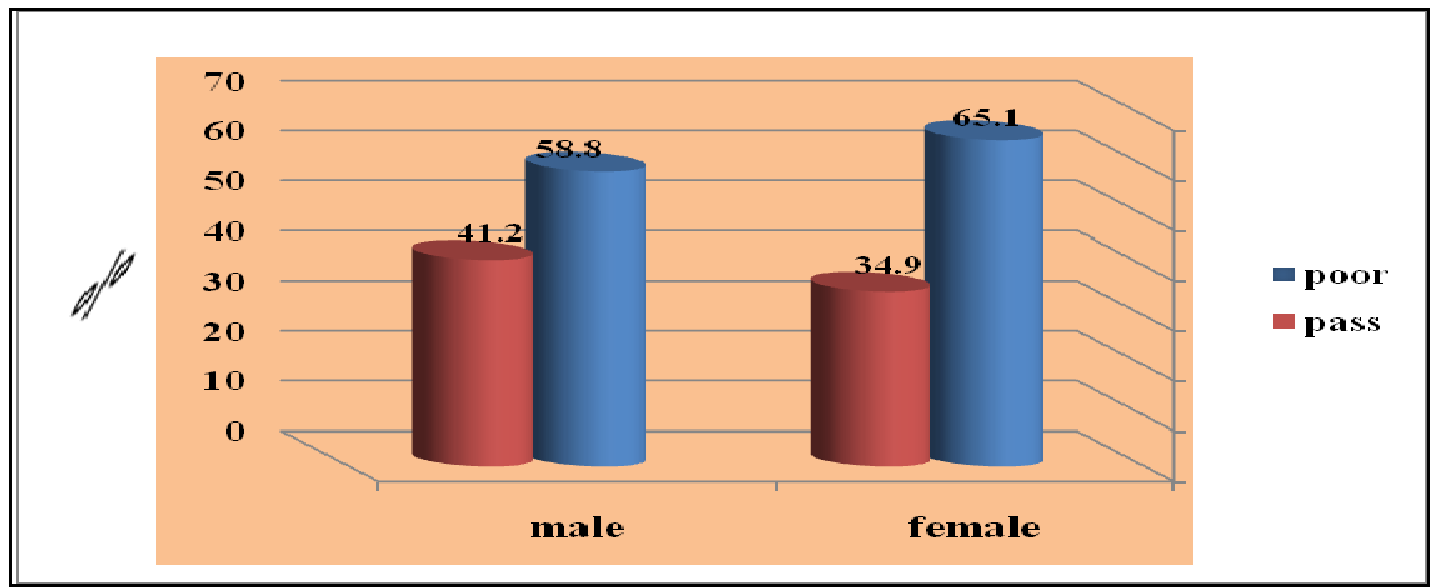

Figure 1:Total knowledge score of the studied sample in relation to their sex

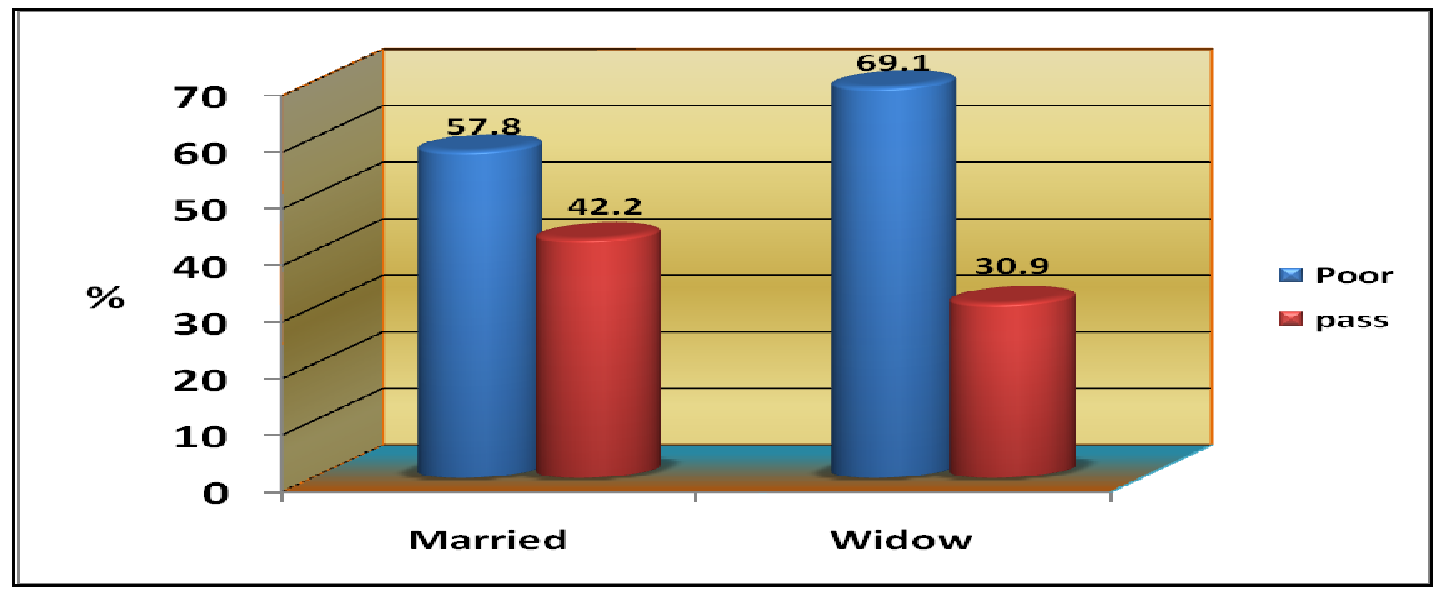

Figure 2: Total knowledge score of the studied sample in relation to their marital status

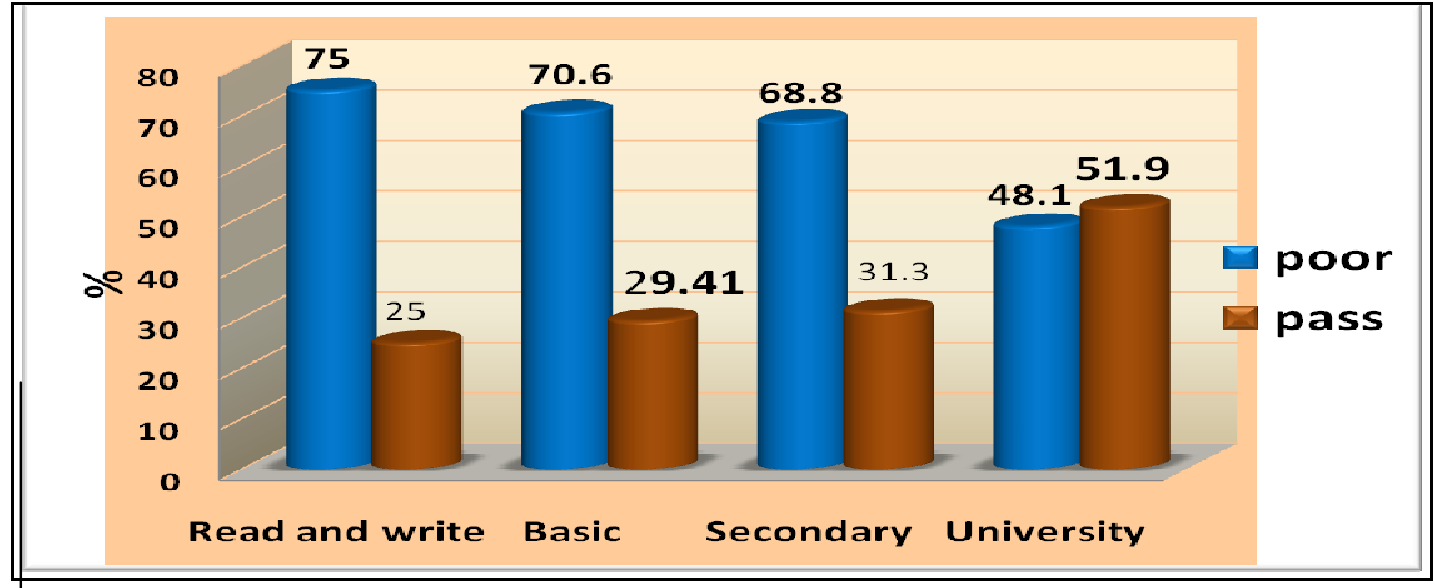

Figure 3:Total knowledge score of the studied sample in relation to their education 


\section{DISCUSSION:}

Urinary tract infection (UTI) is the most frequent infection occurring in elderly men and women. Over the past several years there has been an increasing appreciation of the high frequency of urinary tract infection in this population, and are the second most common cause of infectious disease hospitalization in adults 65 year or older after lower respiratory tract infections (Nicolle, 2000 \& Curns, et al., 2005). The aim of the present study was to assess the elderly knowledge about urinary tract infection.

The finding of this study showed that, the mean age group of the studied sample were (63.9 \pm 4.07$)$. Also $83 \%$ of them were females while the rest of them were males. More than half of the studied sample were widow. Concerning educational status, one fourth of the studied sample had basic education and nearly half of them had secondary education while more than one quarter had university education.

The results of the current study revealed that the majority of elderly men stated enlargement of prostate followed by kidney stone and diabetes mellitus are the most common diseases of elderly that enhancing urinary tract infection. Regarding knowledge of elderly women the majority of them stated diabetes mellitus followed by kidney stone and incontinence as the most common diseases of elderly that enhancing urinary tract infection.

These finding is consistent with (Heath, \& Watson 2003). Who stated that enlargement of the prostate through age-associated changes due to the prostate position affect the transport of urine through the urethra leading to obstruction of the outflow of urine and urinary tract infection.

Also this study in agreement with (Zhanel et al. 1999 \& Haus 1998) who study asymptomatic bacteriuria in patients with diabetes mellitus and reported that diabetes mellitus ranks as the number one coexisting disease state associated with bacteriuria. And the prevalence of asymptomatic bacteriuria is three fold higher among diabetic women than non diabetic women (whereas the rates among men are similar).

The present study in the same line with (Boyko, et al., 2002) who study diabetes and the risk of acute urinary tract infection among postmenopausal women and reported that, diabetes is associated with increased risk of clinically apparent urinary tract infections in postmenopausal women. Also it agree with (Molander, et al., 2000) who study cohort study of elderly women with urinary tract infections and stated that, urinary catheterization and incontinence are risk factors for recurrent urinary tract infection as well as antimicrobial exposure and decreased functional status in institutionalized older adults.

This study found that, the majority of the studied sample stated that decrease fluid intake and increase salt intake followed by lack of personal hygiene, are predisposing factors of urinary tract infection. 
Similar to the present study, (Midthu, 2004) who study criteria for urinary tract infection in the elderly and reported that older women at higher risk for urinary tract infection due to insufficient fluid intake, constipation. Also present study agree with (Morgan, 2004 \& Scholes, 2005) who study risk factors associated with acute pyelonephritis in healthy women and found that low intake of fluids and voluntary urinary retention were associated with urinary tract infection in women.

Also the present study revealed that, the minority of studied sample stated that immobility and constipation are predisposing factors for urinary tract infection. These findings in line with (Abrutyn, et al., 1991, Marchiondo, 1998 \& Midthu, 2004) who reported that constipation and decreased mobility seems to play an important role in increasing infection rates. This relationship may exist because more problems with personal hygiene, increased incidence of incontinence resulting in higher use of indwelling catheters, and fluid imbalances are more common among immobile elders.

In contrast to this study one result of (Eberle, et al., 1993) who study Risk factors and consequences of bacteriuria in non-catheterized nursing home resident and report no association between impaired mobility and asymptomatic bacteriuria.

Regarding elderly knowledge about signs and symptoms of upper urinary tract infections, the majority of the studied sample reported that abdominal pain, followed by headache\& exhausted, while the minority of them reported painful urination. This finding is consistent with (Nicolle, 2000 \& Fune, et al., 1998). Who study infectious diseases in the elderly and reported that elderly with suprapubic, flank, or costovertabral angle pain as evidence of urinary tract infections.

As regards elderly knowledge about signs and symptoms of lower UTIs, the majority of them stated burning pain in urination followed by confusion and frequent urination. These results in line with (Midthun, et al., 2005) who studied urinary tract infection in elderly a survey of physician and nurses, reported that most physicians and nurses were in agreement that traditional signs of a urinary tract infection in the general population-dysuria, urinary frequency, and incontinence-are appropriate for the geriatric as well.

Similar to the present study, (Swen, et al., 2004) who studied the prevalence of lower urinary tract symptoms in men aged 45-79 years and reported that frequent urination was the most common symptom among men aged < 70 years and nocturia among those aged $>70$ years. Other study of (McCue, 1993) who studied urinary tract infections in the elderly and reported that often elderly patients with urinary tract infections will present with symptoms such as delirium, confusion, lethargy and loss of appetite.

Concerning complications of urinary tract infections in the elderly The present study revealed that about three quarter of the studied sample stated inflammation and damage of the kidney followed by recurrent infection and less than one third of them stated incontinence. 
These finding are consistent with study of (Wick et al., 2000) who studied diseases of aging, and reported that in older women, recurrence after an initial urinary tract infection occurs in $60 \%$ of women.

Elderly knowledge about treatment of urinary tract infections, In this study, the majority of them don't know treatment of urinary tract infections and only about one fifth of them stated antibiotics for treatment of urinary tract infections followed by cleaning with antiseptic solution. This because only one quarter of them had history of urinary tract infection. This result similar with (Takahashi, et al., 2004) who studied 196 elderly women $(22 \%$ nursing home residents) and $\mathbf{( 7 8 \%}$ were community dwelling) in Olmsted County Minnesota and found that nursing home residents were more likely to be treated with antibiotics for longer duration than community dwelling elderly.

Regarding elderly knowledge about steps of controlling urinary tract infections, the present study reported that most of the studied sample stated that good personal hygiene followed by drinking fluid and avoid eating salts and spicy foods. These results in agreement with (Tchoudomirova, 1998) who found that genital hygiene practices such as frequency of coitus, urinating after coitus, washing genitals pre coitus, taking baths, frequent replacing of underwear and washing genitals from front to back were associated with a reduced frequency of urinary tract infections,

Also according to a article in urinary tract infection, diagnosis and management for nurses
(Naish \& Hallam, 2007) who reported that personal hygiene after urination or defecation, wipe from front to back, wash hands, drink more fluids and urinate frequently enough to empty the bladder to reduce her risk of infection or prevent future urinary tract infection

The present study also revealed that the minority of elderly stated drink cranberry juice and avoid bubble baths. This finding in contrast with result of (Kontiokari, et al., 2001) Who study randomized trial of cranberrylingonberry juice and Lactobacillus drink for the prevention of urinary tract infections in women who reported that ingestion of "natural" juice drinks to prevent urinary tract infections.

The total knowledge score of the studied sample in relation to their marital status was highest among married elderly women than widow elderly $(42.2 \%, 30.91 \%)$ respectively. This may be due to married women at high risk for infection than widow.

\section{CONCLUSIONS:}

Most of participated elderly do not have enough knowledge regarding definition, causes, predisposing factors, signs and symptoms, treatment, complication and prevention of urinary tract infection and need more information about this important topic.

\section{RECOMMENDATIONS:}

1-Presence of gerontological nurse at geriatric to follow elderly people and give them health education about common diseases, its causes, 
sign and symptoms, risk factor, complication and prevention is very important.

2-Different seminars at geriatric club can be done about interested topics for elderly people such as: normal changes, common health needs and problems for elderly people.

3-Geriatric club library should be rich with specific book about the physiological changes and common health problems among elderly people.

4-Increasing elderly awareness about the importance of periodic check up to detect early health deviation to make early management and to prevent complication through: Health education and focus group discussion for elderly.

\section{REFERENCES:}

Abrutyn E., Mossey J., Levison M, Boscia J., Pitsakis P., \& Kaye D.(1991): Epidemiology of asymptomatic bacteriuria in elderly women. J Am Geriatr Soc 39:388-393.

Basavanthappa, B. (2003): Medical-surgical nursing, chapter14 urinary tract infection, 1 stedition, Jaypee Brother, New Delhi, P:P 716:720.

Beisel B., Hale W., Graves RS, \& Moreland J. (2002): Does postcoital voiding prevent urinary tract infections in young women? J. Fam Pract; 51:977.

Boyko EJ; Fihn SD; Scholes D.; Chen CL; Normand EH; \& Yarbro P, (2002): Diabetes and the risk of acute urinary tract infection among postmenopausal women. Diabetes Care 2002 Oct; 25(10) :

1778-83.

Central Intelligence Agency (2007): the world fast book. Field listing-age StructureUpdated 8 March 2007.

Eberle C, Winsemius MD, \& Garibaldi RA. (1993): Risk factors and consequences of bacteriuria in non-catheterized nursing home residents. J. Gerontol 48:M266271.

Eidelman Y., Raveh D., \& Yinnon AM, (2002): Reagent strip diagnosis in a high-risk population. AM J. Emerg Med; 20 :112113.

Fune, L., Shua-Haim, J., Ross, J., \& Frank, E. (1998): Infectious diseases in the elderly. Clinical Geriatrics, 6(3), 31-50.

Haus E. (1998): Urinary tract infections in the homebound elderly. Home Healthcare Nurse. 16, 5, 323-327. Journal of the American Geriatrics Society. 39, 4, 388393.

Heath, T., \& Watson, R. (2003): Promoting Continence (pp 81-106). Edingburg, UK: Elsevier Science Ltd.

Jepson, RG, \& Craig, JC (2008): "Cranberries for preventing urinary tract infections." Cochrane Data Base Syst Rev CD001321.

Marchiondo, K., (1998): A new look at urinary tract infection. American Journal of Nursing. 98, 3, 34-38. McGraw-Hill, : 1620-6.

McCue JD. (1993): Urinary tract infections in the elderly. Pharmacotherapy 13: S51-3.

Midthum SJ, (2004): Criteria for urinary tract infection in the elderly: Variables that 
challenge nursing assessment 57-162 \& 166-170.

Midthun, S, Ruth P \&Peter Midthun BA (2005): Urinary Tract Infections in the Elderly: A Survey of Physicians and Nurses Available online 16 August 2005.

Miller, C., A., (2009): Nursing for wellness in older adults, Nursing theory interventions to promote healthy urinary function, $5^{\text {th }}$ edition, Lippincott, willins $\&$ wikins, New York, P:P 309:334.

Molander U., A. L., Milsom I., \& Sandberg T. (2000): A longitudinal cohort study of elderly women with urinary tract infections; 34: 127-131.

Morgan, K.L., (2004): Management of UTIs during pregnancy, "American Journal of maternal and child ? Nursing 29 (4): 254 58.

Naish W.,\& Hallam, (2007): Urinary tract infection: diagnosis, and management for nurses. Nursing standers. 21, 23, 50, 57. New York, P:P 309:334.

Nicolle, LE., (2000): Urinary tract infection in long-term-care facility residents. Clin Infect Dis. 2000; 31: 757-761.

Nicolle LE., Bradley S, \& Colgan R, (2005): Infectious Diseases Society of America; American Society of Nephrology; American Geriatrics Society. Infectious Diseases Society of America guidelines for the diagnosis and treatment of asymptomatic bacteriuria in adults. Clin Infect Dis.; 40: 643-654.

Roach, S.,(2001): Introductory of gerontological nursing, age related changes of the genitourinary tract, Chapter 22, $1^{\text {st }}$ edition. Lippincott, New York, p:p 294295.

Scholes D. (2005): Risk factors associated with acute pyelonephritis in healthy women. Annals of internal medicine, 2005, 142:20-7.

Smelters S.C., Bare B.G, Hinkle J.L., \& Cheever K. H., (2008): Text book of medical-surgical nursing. Chapter 45, Infection of the urinary tract, $\left(11^{\text {th }}\right.$ Edition), Lippincott company, P:P 15701580 .

Swen O. A., Bahram R., Lars rlberg, A., Wolk and Jan-Erik Johansson, (2004), Prevalence of Lower Urinary Tract Symptoms In Men Aged 45-79 Years: A Population-Based Study of 40000 Swedish Men.

Takahashi P., Trang N., and Chutka D., (2004): Antibiotic Prescribing and Outcomes Following Treatment of Symptomatic urinary tract infections in older women. JAMDA 2004; 5: S12-S15.

Tchoudomirova K., (1998): History, clinical findings, sexual behavior and hygiene habits in women with and without recurrent episodes of urinary symptom. Acta bstetricia et gynecologica Scandinavica, 1998, 77(6):654-6.

Wick G., Jansen-Durr P., \& Berger P. (2000): Diseases of aging. 18: 1567-1583.

Zhanel GG, Harding GKM, \& Nicole E, (1999): Asymptomatic bacteriuria in patients with diabetes mellitus. Rev Infect Dis.;13:150-4. 


$$
\begin{aligned}
& \text { تقييم معلومات المسنيـن عن عدوى المسالك البولية في مدينة أسيوط }
\end{aligned}
$$

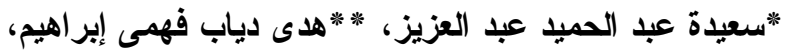

$$
\begin{aligned}
& \text { "نعمة محمد المغربى، "*قصفاء رشاد محمود } \\
& \text { "قسم تمريض المسنين - كلية التصريض -جامعة أسبيوط } \\
& \text { *قتم تمريض صحة المجتمعكلية التمريض -جامعة أسبيوط }
\end{aligned}
$$

تعتبر التهابات المسالك البولية من أهم المشاكل الصحية الأكثر شيوعا بين المسنين, فهناك أكثر من 20\%

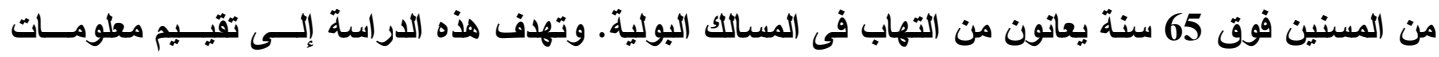

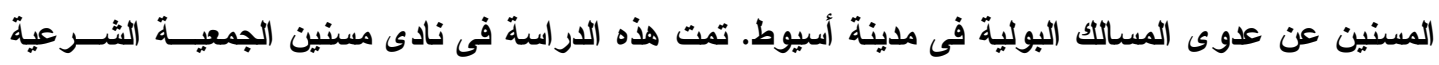

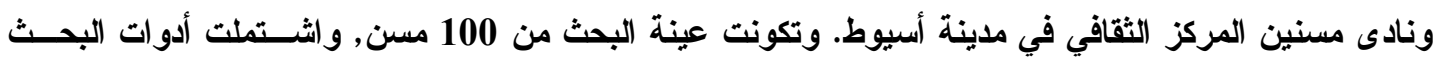

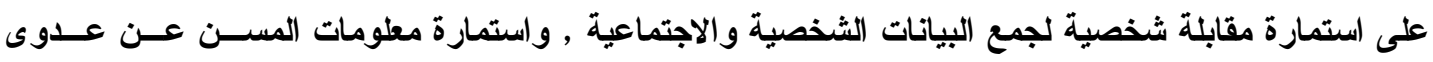

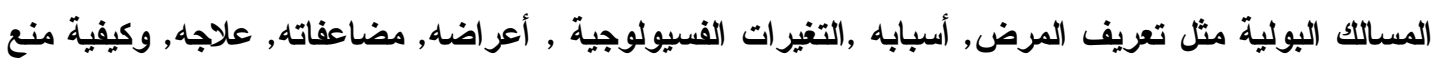

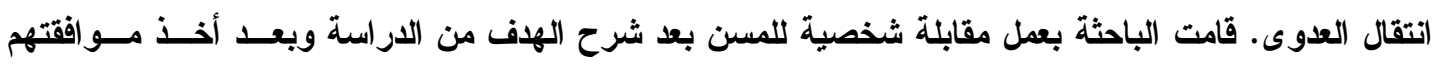

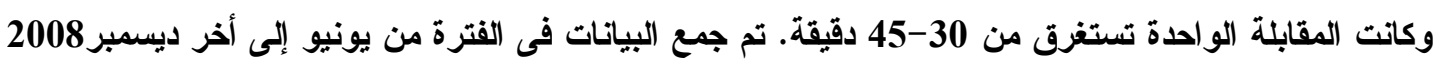

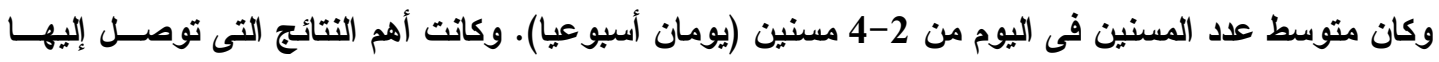
البحث كالتالمي:-

وجد أن متوسط أعمار المسنين يتراوح بين 60-80 عاما, وأغلبية العينة 83\% من الإناث وأكثر من 55\%

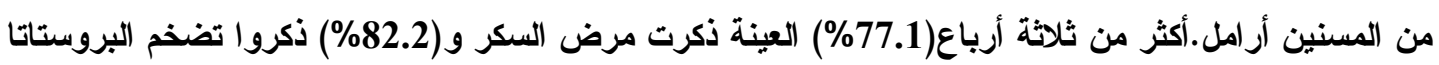

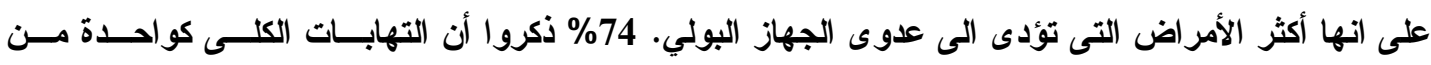
مضاعفات عدوى الجهاز البولي. معظم عينة البحث ذكرت النظافة الشخصية كطريقة لمنع عدوى لوى الجهاز البولي

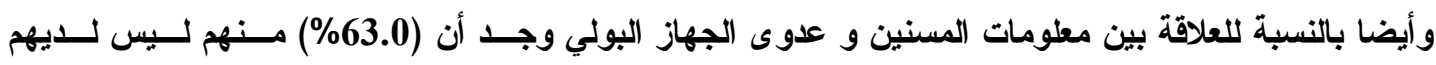

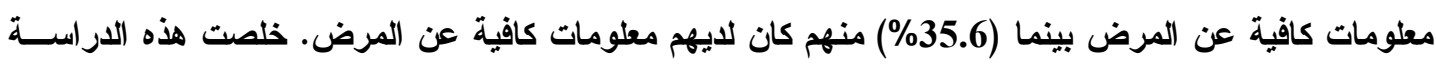

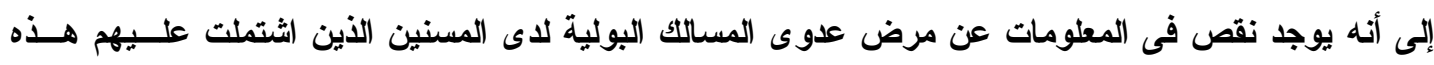

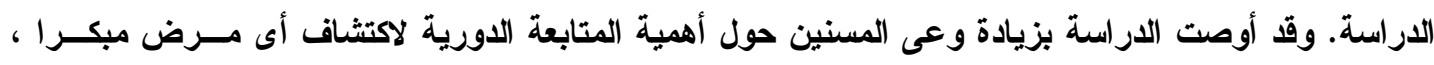
إعطاء التثقيف الصحي للمسنين عن التغيرات الطبيعية التي تحدث لهم وعن أهم المشاكل التي تواجه المســنين,

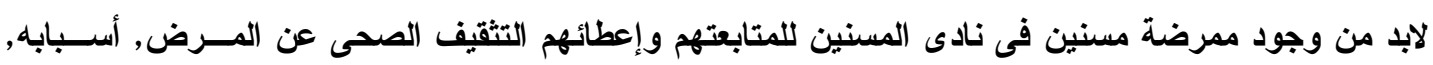
أعراضه, مضاعفاته, علاجه, وكيفية منعه.تزويد مكتبة نادي المسنين بالكتب الخاصة بفئة المسنين. 